\title{
Three new red algal parasites from New Zealand: Cladhymenia oblongifoliaphila sp. nov. (Rhodomelaceae), Phycodrys novae-zelandiaephila sp. nov. (Delesseriaceae) and Judithia parasitica sp. nov. (Kallymeniaceae)
}

\author{
Maren Preuss $^{1 *}$ and Giuseppe C. Zuccarello ${ }^{1}$ \\ ${ }^{1}$ School of Biological Sciences, Victoria University of Wellington, PO Box 600, Wellington, 6140, New Zealand
}

\begin{abstract}
AвSTRACT: There are over 120 species of red algal parasites (Florideophyceae) but they are often overlooked due to their small size and patchy distribution. Red algal parasites have mostly been described as independent genera but recent phylogenetic studies have shown that parasites are related to free-living relatives, often their hosts, and have been named in these genera to maintain monophyly. We investigated the morphology, distribution and phylogeny, using diverse molecular markers (mitochondrial, nuclear, plastid), of three new red algal parasites in New Zealand. We describe the parasites using morphological and anatomical observations and estimate their distribution by surveying herbarium vouchers. Analyses of reproductive structures and molecular phylogenies indicate that the closest relative of the parasite Phycodrys novaezelandiaephila sp. nov. is its host, Phycodrys novae-zelandiae. Based on nuclear and mitochondrial markers, the closest relative of the parasite Cladhymenia oblongifoliaphila sp. nov. is its host Cladhymenia oblongifolia but plastid markers group it with Cladhymenia lyallii, suggesting that this species was a past host and the source of parasite plastids. The parasite Judithia parasitica sp. nov. groups with Judithia delicatissima but infects Blastophyllis spp., suggesting that this parasite evolved as a free-living or parasitic Judithia species, and host switching may have occurred. This study adds to our knowledge of New Zealand red algal parasites and highlights contrasting patterns of host-parasite relationships.
\end{abstract}

Key Words: Biodiversity, Ceramiales, Emery's rule, Gigartinales, Monophyletic taxonomy, Parasitism, Phylogenetics, Plastid capture, Rhodophyta, Speciation

\section{INTRODUCTION}

Red algal parasites, a poorly studied polyphyletic category with many unique features, are found exclusively on red algal species in eight orders within the Florideophyceae (Blouin \& Lane 2015; Preuss et al. 2017). Approximately 120 species have been described world-wide but their diversity is probably severely underestimated due to their small size and patchy distribution (Preuss et al. 2017). Four key characters are used to identify red algae as parasitic: (1) reduced size, (2) lack of or reduced pigmentation, (3) formation of secondary pit connection between parasite and host cells and (4) both gametophytic and sporophytic parasite life stages on the same host stage (Wynne \& Scott 1989). In the past, similarities in reproductive structures were used to indicate a close taxonomic relationship ('adelphoparasites') or more distant relationship ('alloparasites') between parasite and host combinations (Goff 1982); whereas, more recent phylogenetic data indicate a continuum of relatedness between hosts and parasites (e.g. Zuccarello et al. 2004; Blouin \& Lane 2012).

The close relationship between most red algal parasites and their hosts led to a hypothesis that these parasites evolved directly from their hosts (Setchell 1918), consistent with the entomological concept known as 'Emery's rule' (Emery 1909). Later molecular evidence supported Emery's rule (Goff et al. 1997) but also revealed varied phylogenetic relationships. Several studies showed that some parasites are more closely related to their hosts than the host is to other

\footnotetext{
* Corresponding author (Maren142@web.de).

DOI: $10.2216 / 17-36.1$

(C) 2018 International Phycological Society
}

species in the same genus (Goff et al. 1997; Zuccarello et al. 2004; Preuss \& Zuccarello 2014), while parasites with multiple hosts in different genera [e.g. Harveyella mirabilis (Reinsch) F.Schmitz \& Reinke] have undergone host switching (Zuccarello et al. 2004; Kurihara et al. 2010). Previous studies indicated that the plastid was mobile between hosts and parasites with the parasite 'capturing' the host plastid (Goff \& Coleman 1995; Goff et al. 1996), a phenomenon that was not seen with the mitochondria (Goff \& Coleman 1995). This led to varied relationships between hosts and parasites using plastid sequence data and could be used to indicate parasite origins and host switching. For example, parasites can have similar, occasionally nearly identical, plastid gene sequences to the host (e.g. Rhodophyllis parasitica M.Preuss \& Zuccarello; Preuss \& Zuccarello 2014), matching the relationships of the nuclear and mitochondrial markers, indicating a recent evolution from the host species. Parasites can have plastids more closely related to another species of host from the host they are found on [e.g. Gracilaria babae (H.Yamamoto) P.K.Ng, P.E.Lim \& Phang; $\mathrm{Ng}$ et al. 2014], indicating that the parasite acquired its plastids from a previous host. Recent studies have also shown that parasites can have a highly reduced plastid genome relative to that of the host (e.g. Choreocolax polysiphoniae Reinsch; Salomaki et al. 2015), possibly indicating a long history of parasitism.

Previously, newly described parasites were grouped into independent parasitic genera (e.g. Kraft \& Abbott 2002; Townsend \& Huisman 2004; Vergés et al. 2005; Kim \& Cho 2010). Several phylogenetic studies have now shown that parasites and hosts are often closely related to each other, using nuclear and mitochondrial markers, and parasites have 
origins within the host genus but still distinct parasite generic names were retained (e.g. Goff et al. 1996; Kurihara et al. 2010). Newer studies support a strictly monophyletic scheme reflecting the integration of the parasites into the host genus based on phylogenetic support (Ng et al. 2014; Preuss \& Zuccarello 2014).

Of the 120 recognised red algal parasite species, 10 are currently known from New Zealand (Preuss et al. 2017). Five species were described from New Zealand, and the others were recorded for New Zealand but described from other parts of the world. The five described parasites from New Zealand are Colacopsis lophurellae Kylin, Gloiocolax novaezelandiae Sparling, Gonimophyllum insulare F.S.Wagner, Pterocladiophila hemisphaerica K.C.Fan \& Papenfuss and Rhodophyllis parasitica. The five remaining species are Callocolax neglectus F.Schmitz \& Batters, Choreonema thuretii (Bornet) F.Schmitz, Colacodasya inconspicua (Reinsch) F.Schmitz, Microcolax botryocarpa (Hooker f. \& Harvey) F.Schmitz and Sporoglossum lophurellae Kylin. Molecular data are available only for Rhodophyllis parasitica (Preuss \& Zuccarello 2014).

In this study, we describe three new red algal parasite species from New Zealand: one found on Cladhymenia oblongifolia Hooker f. \& Harvey, one on Phycodrys novaezelandiae Showe M.Lin \& W.A.Nelson; and one species found on both Blastophyllis calliblepharoides (J.Agardh) D'Archino \& W.A.Nelson and Blastophyllis hombroniana (Montagne) D'Archino \& W.A.Nelson.

\section{MATERIAL AND METHODS}

Samples were collected mostly as drift around New Zealand (Table S1). All specimens were pressed as herbarium vouchers, dried in silica gel or fixed in $2 \%$ glutaraldehyde in phosphate buffer $(0.1 \mathrm{M}, \mathrm{pH} 6.8)$ in $50 \%$ seawater.

For anatomical observations, sections were either embedded in resin following Preuss \& Zuccarello (2014) or hand sectioning with a razor blade. Sections were stained with $1 \%$ acidified aniline blue in either water or $50 \%$ karo syrup (ACH Food Co., Englewood Cliffs, New Jersey USA). Samples were examined using Olympus AX-70 and Olympus BX53 microscopes (Tokyo, Japan) with integrated cameras (Olympus DP-70, Olympus SC100), and images were captured using Olympus CellSens Software (2017).

DNA was extracted either using 5\% Chelex following Zuccarello et al. (1999) or following a modified cetyl trimethyl ammonium bromide protocol (Zuccarello \& Lokhorst 2005). Mitochondrial ( $\operatorname{cox} 1)$, nuclear [actin, large subunit (LSU) rDNA, small subunit (SSU) rDNA] and plastid $(r b c \mathrm{~L})$ markers were used for analysis (Table S2). Polymerase chain reaction (PCR) conditions for actin amplification were as follows: initial denaturation at $94^{\circ} \mathrm{C}$ for $5 \mathrm{~min}$, followed by nine cycles of $94^{\circ} \mathrm{C} / 55^{\circ} \mathrm{C} / 72^{\circ} \mathrm{C}$ for 1 min each, followed by 29 cycles of $94^{\circ} \mathrm{C}$ for $30 \mathrm{~s}, 45^{\circ} \mathrm{C}$ and $72^{\circ} \mathrm{C}$ for $1 \mathrm{~min}$ and a final step at $72^{\circ} \mathrm{C}$ for $10 \mathrm{~min}$. PCR conditions for all other genes were carried out with an initial denaturation at $94^{\circ} \mathrm{C}$ for $5 \mathrm{~min}$, followed by 36 cycles of $94^{\circ} \mathrm{C} / 45^{\circ} \mathrm{C} / 72^{\circ} \mathrm{C}$ for $1 \mathrm{~min}$ each and a final step at $72^{\circ} \mathrm{C}$ for 5 min. Successful amplifications were purified using ExoSAP-
IT following manufacturer's instructions (USB product; Affymetrix, Santa Clara, California USA) and commercially sequenced (Macrogen Inc., Seoul, South Korea).

New sequences were assembled and edited in Geneious 8.0.5 (http://www.geneious.com, Kearse et al. 2012). Genbank sequences were added to the alignments following D'Archino et al. (2017) or using the closest Basic Local Alignment Search Tool search hits (Table S3). Multiple Alignment using Fast Fourier Transform alignments implemented in Geneious were used and modified by eye. Bayesian inference was performed with MrBayes v.3.2.5 (Ronquist \& Huelsenbeck 2003). Analyses consisted of two independent simultaneous runs of one cold and three incrementally heated chains, and $3 \times 10^{6}$ generations with sampling every 1000 generations. A 'burn-in' of $5 \times 10^{5}$ generations was used, and 25,000 trees were saved to make the consensus tree. RAxML 7.2.8 (Stamatakis 2006) was used to construct maximum-likelihood (ML) trees to show the most likely tree from the data set. RAxML was performed using the General Time Reversible + gamma model and 500 non-parametric bootstrap replicates (Felsenstein 1985). RAxML and Bayesian inference was performed with all three codons partitioned for $\operatorname{cox} 1$ and $r b c \mathrm{~L}$. Phylogenies of $c o x 1$, LSU and $r b c \mathrm{~L}$ sequences of the parasite growing on Blastophyllis spp. and of cox 1 and LSU sequences of the parasite growing on Cladhymenia sp. were congruent (Supplementary Figs S1-S5), and the data sets were concatenated (with partition for LSU and partitioned codons for cox 1 and $r b c \mathrm{~L}$ ) for a more robust phylogeny.

All alignments of the Phycodrys parasite and its host were analyzed for genetic diversity using TCS statistical parsimony networks (Clement et al. 2000) in PopArt 1.7 (http:// popart.otago.ac.nz). Phycodrys adamsiae Showe M.Lin \& W.A.Nelson was used as comparison of interspecific variation within Phycodrys.

Unique sequences were deposited in Genbank (MF319122-MF319182).

Herbarium specimens of Blastophyllis calliblepharoides, Blastophyllis hombroniana, Cladhymenia oblongifolia and Phycodrys novae-zelandiae at the Museum of New Zealand Te Papa Tongarewa (WELT) in Wellington were searched for parasites and observed parasites listed.

\section{RESULTS}

Three unrecorded parasites were found throughout New Zealand with the exception of the host species Blastophyllis hombroniana (as Callophyllis hombroniana) from which a parasite was recorded previously (Cotton 1907).

\section{Parasite on Phycodrys novae-zelandiae}

All genetic markers showed the same pattern and indicated a very close relationship between Phycodrys novae-zelandiae and its parasite.

Partial cox 1 sequences (623 bp) were obtained for six samples of Phycodrys novae-zelandiae and three of its parasites. Genetic distances within $P$. novae-zelandiae ranged between 0.16 and $0.64 \%$ ( 1 and $4 \mathrm{bp}$ ), and between the parasite and host 0.0 and $1.12 \%$ (0 and $9 \mathrm{bp}$ ) and up to $0.8 \%(5 \mathrm{bp})$ between parasite specimens. Four haplotypes were found: $\mathrm{Cl}-$ 


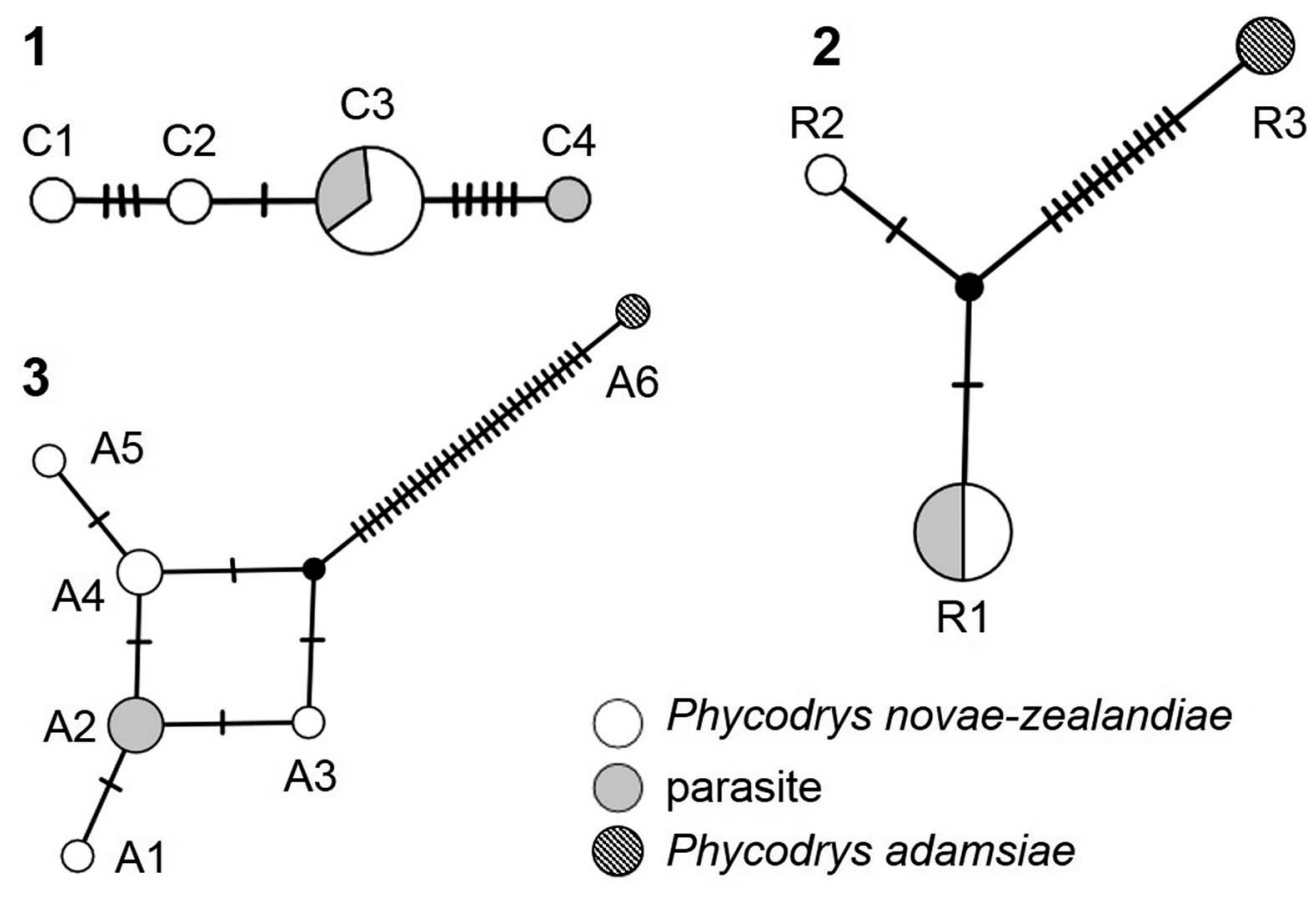

Figs 1-3. DNA sequence networks of Phycodrys novae-zelandiae, its parasite Phycodrys novae-zelandiaephila and Phycodrys adamsiae.

Fig. 1. Cox 1 haplotype network with four different haplotypes $(\mathrm{C} 1-\mathrm{C} 4)$.

Fig. 2. $R b c \mathrm{~L}$ haplotype network with three different haplotypes (R1-R3).

Fig. 3. Actin haplotype network with six haplotypes (A1-A6). Small dark circle represents missing intermediates, lines $=$ one mutational step. Parasite, host and P. adamsiae haplotypes highlighted in white, gray and hatched, respectively.

C4. Five hosts and two parasites had Haplotype C3, while C1 and $\mathrm{C} 2$ were represented in one host specimen each. $\mathrm{C} 4$ was represented in one parasite specimen (Fig. 1).

Partial $r b c \mathrm{~L}$ sequences of $530 \mathrm{bp}$ were obtained from Phycodrys novae-zelandiae $(n=4)$, its parasite $(n=3)$ and Phycodrys adamsiae $(n=2)$. Three haplotypes were found: R1-R3. Three hosts and three parasites had haplotype R1, while R2 was represented in one host specimen and R3 in two specimens of Phycodrys adamsiae (Fig. 2).

Actin sequences of $638 \mathrm{bp}$ were obtained from Phycodrys novae-zelandiae $(n=4)$, its parasite $(n=3)$ and Phycodrys adamsiae $(n=2)$. Six haplotypes were found: A1-A6. All three parasites had haplotype A2, while A1, A3, A4 and A5 was represented in one host sample each, and A6 in two specimens of P. adamsiae (Fig. 3).

The partial SSU alignment (827 bp) for Phycodrys novaezelandiae $(n=3)$ and its parasite $(n=3)$ showed that all sequences of host and parasite were identical (data not shown).

The molecular data of the parasite and its host, Phycodrys novae-zelandiae, showed the same pattern of low or no variation for all four genes from different genomes and demonstrated that the parasite is closely related to its host. This new parasite belongs in the genus Phycodrys.

\section{Phycodrys novae-zelandiaephila M.Preuss \& Zuccarello sp. nov.} Figs 4-12

DIAGNOSIS: Thalli lightly pigmented (pale red), size $1-2 \mathrm{~mm}$ across, with multiple simple branches. Dioecious gametophytes. Carposporophyte $430-530 \mu \mathrm{m}$ in diameter, surrounded by a pericarp, with rows of carposporangia. Spermatangia unknown. Tetrasporangia $40 \mu \mathrm{m}$ long $\times 32 \mu \mathrm{m}$ wide, tetrahedrally divided, scattered on surface of stichidial branches. Parasitic on Phycodrys novae-zelandiae Showe M.Lin \& W.A.Nelson.

HOLOTYPE: WELT A033494, collected 27 November 2015, deposited in the Museum of New Zealand Te Papa Tongarewa.

GENBANK ACCESSION NUMBERS: cox1, MF319155, MF319157; $r b c \mathrm{~L}$, MF319166; actin, MF319160; SSU, MF319164.

ISOTYPE: WELT A033494, collected 27 November 2015, deposited in the Museum of New Zealand Te Papa Tongarewa.

TYPE LOCALITY: $41^{\circ} 43.667^{\prime} \mathrm{S}, 174^{\circ} 12.917^{\prime} \mathrm{E}$; drift, Marfells Beach, South Island, New Zealand.

ETYMOLOGY: novae-zelandiaephila refers to the parasite's affinity to its host Phycodrys novae-zelandiae.

DISTRIBUTION: The collection at Te Papa contained 52 specimens of Phycodrys novae-zelandiae of which red algal parasites were observed on nine. The parasite was found from Mataikona $\left(40^{\circ} 47^{\prime} \mathrm{S}\right)$ on the North Island to Stewart Island $\left(46^{\circ} 55^{\prime} \mathrm{S}\right)$, south of the South Island (Table S4).

\section{Habitat and vegetative morphology}

Phycodrys novae-zelandiaephila grew on blades of Phycodrys novae-zelandiae, which had over 20 parasites on one blade, usually growing on the veins of the host (Fig. 4). Phycodrys novae-zelandiaephila was found in spring (September, November), summer (January, February) and autumn (March, April) (Table S1, S4). 

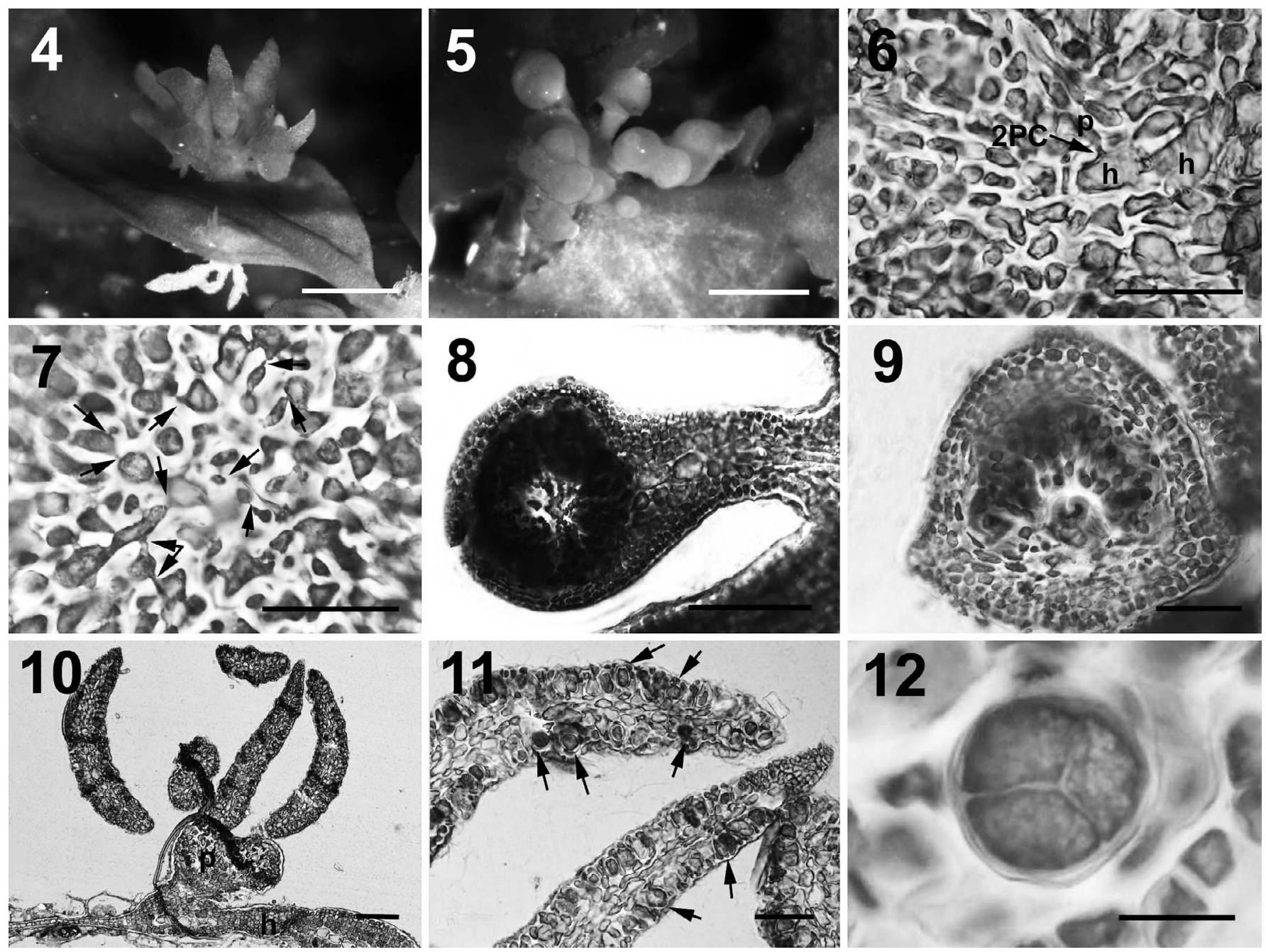

Figs 4-12. Vegetative and reproductive structures of Phycodrys novae-zelandiaephila sp. nov. on its host Phycodrys novae-zelandiae.

Fig. 4. Habit of a tetrasporophytic parasite growing on the central vein of its host. Scale bar $=1 \mathrm{~mm}$.

Fig. 5. Habit of cystocarpic gametophyte growing on host thallus. Scale bar $=1 \mathrm{~mm}$.

Fig. 6. Contact area between parasite and host. Parasite cell (p) forms secondary pit connection (2PC; arrow) with host cell (h). Scale bar $=$ $100 \mu \mathrm{m}$.

Fig. 7. Parasite cells are highly connected with each other. Arrows indicate pit connections. Scale bar $=100 \mu \mathrm{m}$.

Fig. 8. Branch with mature cystocarp of parasite. Central fusion cell visible. Scale bar $=250 \mu \mathrm{m}$.

Fig. 9. Close-up of cystocarp of parasite, showing pericarp of approximately five cell layers. Scale bar $=100 \mu \mathrm{m}$.

Fig. 10. Cross section of parasite (p) tetrasporangial stichidia on its hosts (h). Scale bar $=200 \mu \mathrm{m}$.

Fig. 11. Tetraspores scattered on the surface of the tetrasporangial stichidia, tetrasporangia indicated by arrows. Scale bar $=100 \mu \mathrm{m}$.

Fig. 12. Mature tetrahedrally divided tetrasporangium. Scale bar $=20 \mu \mathrm{m}$.

The thallus was light red, 1-2 mm in size (Figs 4, 5). It had a single base that penetrated and disrupted the cell layers of the host. Host cells were embedded between parasite tissue in the contact area. Secondary pit connections were found between large host cells and smaller parasitic cells in the contact area (Fig. 6). The cells within the main body of the parasite thallus were highly connected, by either primary or secondary pit connections (Fig. 7).

\section{Reproductive morphology}

Female gametophytes and tetrasporophytes were observed. Thalli bear branches with either fusiform stichidia bearing tetraspores (Fig. 4) or apical, rounded cystocarps (Fig. 5). All observed parasites were reproductive but males were not found, suggesting dioecious gametophytes.

The female gametophyte had a narrow, pulvinate base that gave rise to several unbranched axes, most of which terminate in an apical cystocarp. Branches were polystromatic with a central axis of large cells surrounded by up to five layers of smaller cells. The inner layer of elongated cortical cells was spherical near the mature carposporophyte (Fig. 8). The mature carposporophytes were approximately $430-530 \mu \mathrm{m}$ in diameter and surrounded by an approximately five cell thick pericarp $(62 \mu \mathrm{m} ; n=9)$. The carposporophyte had a single central fusion cell that gave rise to rows of gonimoblast filaments. Carpospores were 


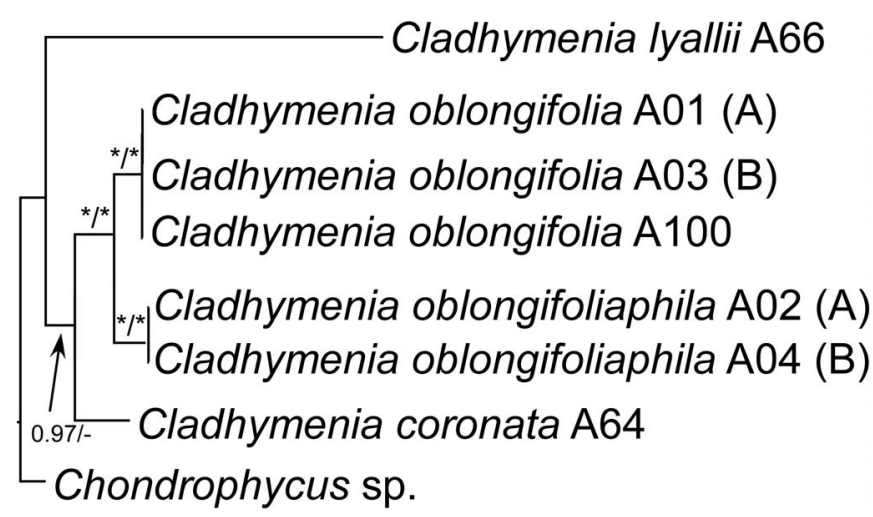

Fig. 13. Bayesian topology of concatenated $\operatorname{cox} 1$ and LSU rRNA sequence dataset for Cladhymenia oblongifolia, its parasite Cladhymenia oblongifoliaphila and two other Cladhymenia species: $C$. coronata and C. lyallii. Host and parasite from the same host plant are highlighted by capital letters in parentheses (A, B). Details of collections in Table S1. Asterisks indicate posterior probability of 1.00 and bootstrap values of $100 \%$. Values $<85 \%$ ML bootstrap not shown. Outgroup was Chondrophycus sp.

borne in short chains of approximately four ovoid carpospores $(19 \times 10 \mu \mathrm{m}$; Fig. 9).

The tetrasporophyte grew from a rounded base approximately $500 \mu \mathrm{m}$ in diameter. The base produced multiple simple fusiform branches that rarely branch again (Figs 4, 10). Branches had scattered stichidia on their surfaces. The stichidial branch was around $654 \times 207 \mu \mathrm{m}(n=2)$ in size (Fig. 10) with two to three inner layers of elongated cells and scattered globose tetrasporangia on the surface (Fig. 11). Tetrasporangia were tetrahedrally divided approximately $32 \times$ $40 \mu \mathrm{m}(n=10$; Fig. 12).

Comparison to host species and other parasites on congeneric host species

The parasite shared carpospores borne in chains, from a central fusion cell and tetrahedrally divided tetraspores with its host species (Phycodrys novae-zelandiae) and two other Phycodrys species (Phycodrys adamsiae, Phycodrys franiae Showe M.Lin \& W.A.Nelson) but differed in most other characters (Table S5). The new parasite was similar to other parasites [Asterocolax denticulatus (Tokida) Feldmann \& Feldmann-Maz., Asterocolax gardneri (Setchell) Feldmann \& Feldmann-Maz.] on Phycodrys spp., with similar thalli size and pigmentation, tetrahedrally divided tetraspores shattered over the surface, and apical cystocarp that were borne on branches. It differed in geographical distribution and host species (Table S6).

\section{Parasite on Cladhymenia oblongifolia}

The concatenated data set (1613 bp) of cox 1 and LSU rRNA contained eight samples of two parasite samples and their hosts, an uninfected Cladhymenia oblongifolia and two other Cladhymenia species (individual gene data sets were similar supplementary data Figs 1, 2). This dataset supported the shared origin of the parasite and its host $C$. oblongifolia with strong support (Fig. 13). Cladhymenia coronata (Lindauer \& Setchell) P.Saenger and Cladhymenia lyallii Harvey were distinct from $C$. oblongifolia and its parasite.

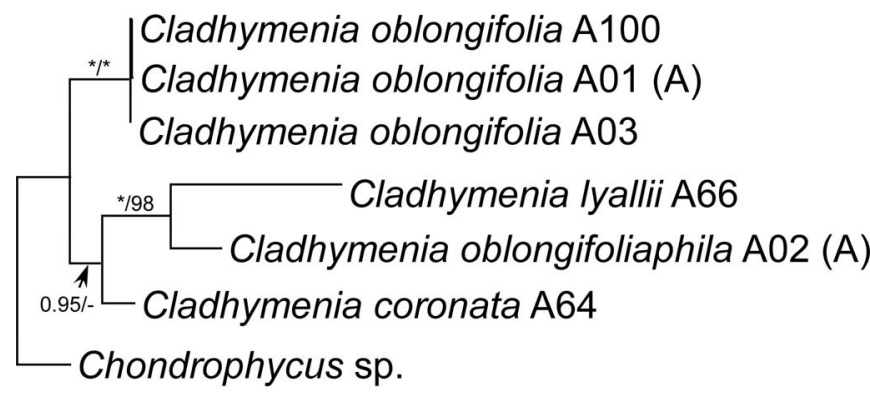

Fig. 14. Bayesian topology of $r b c \mathrm{~L}$ relationships for Cladhymenia oblongifolia, its parasite Cladhymenia oblongifoliaphila and two other Cladhymenia species: C. coronata and C. lyallii. Parasite and host combination is highlighted by capital letter in parentheses (A). Details of collections in Table S1. Asterisks indicate posterior probability of 1.00 and bootstrap value of $100 \%$. Values $<85 \% \mathrm{ML}$ bootstrap not shown. Outgroup used was Chondrophycus sp.

The partial $r b c \mathrm{~L}$ data set $(537 \mathrm{bp})$ contained taxa representative of all three Cladhymenia species in New Zealand. All samples of Cladhymenia oblongifolia grouped with high support (Fig. 14). The parasite grouped with Cladhymenia lyallii with high support, and not C. oblongifolia as with the previous markers, and both appeared to be sister to Cladhymenia coronata but this relationship was only supported in the ML analysis.

The phylogenetic data of the parasite growing on Cladhymenia oblongifolia showed two different patterns. Mitochondrial ( $\operatorname{cox} 1)$ and nuclear (LSU rRNA) data showed a shared ancestry of the parasite and host. The plastid marker showed a common ancestor between the parasite plastid and plastids of Cladhymenia lyallii.

Our phylogenetic data, plus no records of parasites on Cladhymenia, indicated that this parasite is new and belongs within the genus Cladhymenia. It is described here as a new species.

\section{Cladhymenia oblongifoliaphila M.Preuss \& Zuccarello sp. nov. Figs 15-23}

DIAGNOSIS: Thalli unpigmented, $2 \mathrm{~mm}$ across, with either smooth spheres or one roundish cushion. Dioecious gametophytes. Carposporophyte approximately $520-570 \mu \mathrm{m}$, surrounded by a pericarp, no ostiole. Carposporangia, 55-100 × 14-24 $\mu \mathrm{m}$, long and clavate to lachrymiform. Spermatangia unknown. Tetrasporangia 45 $55 \mu \mathrm{m}$ across, tetrahedrally divided, formed in branches. Parasitic on Cladhymenia oblongifolia.

HOLOTYPE: WELT A033496, collected 21 September 2015, deposited in Museum of New Zealand Tongarewa (Te Papa).

GENBANK ACCESSION NUMBERS: cox1, MF319141; LSU, MF319145; $r b c \mathrm{~L}, \mathrm{MF} 319151$.

ISOTYPE: WELT A033496, collected 21 September 2015, deposited in Museum of New Zealand Tongarewa (Te Papa).

TYPE LOCALITY: $41^{\circ} 43.667^{\prime} \mathrm{S}, 174^{\circ} 12.917^{\prime} \mathrm{E}$; drift; Marfells Beach, South Island, New Zealand.

ETYMOLOGY: oblongifoliaphila refers to the preference of the parasite to grow on Cladhymenia oblongifolia. 

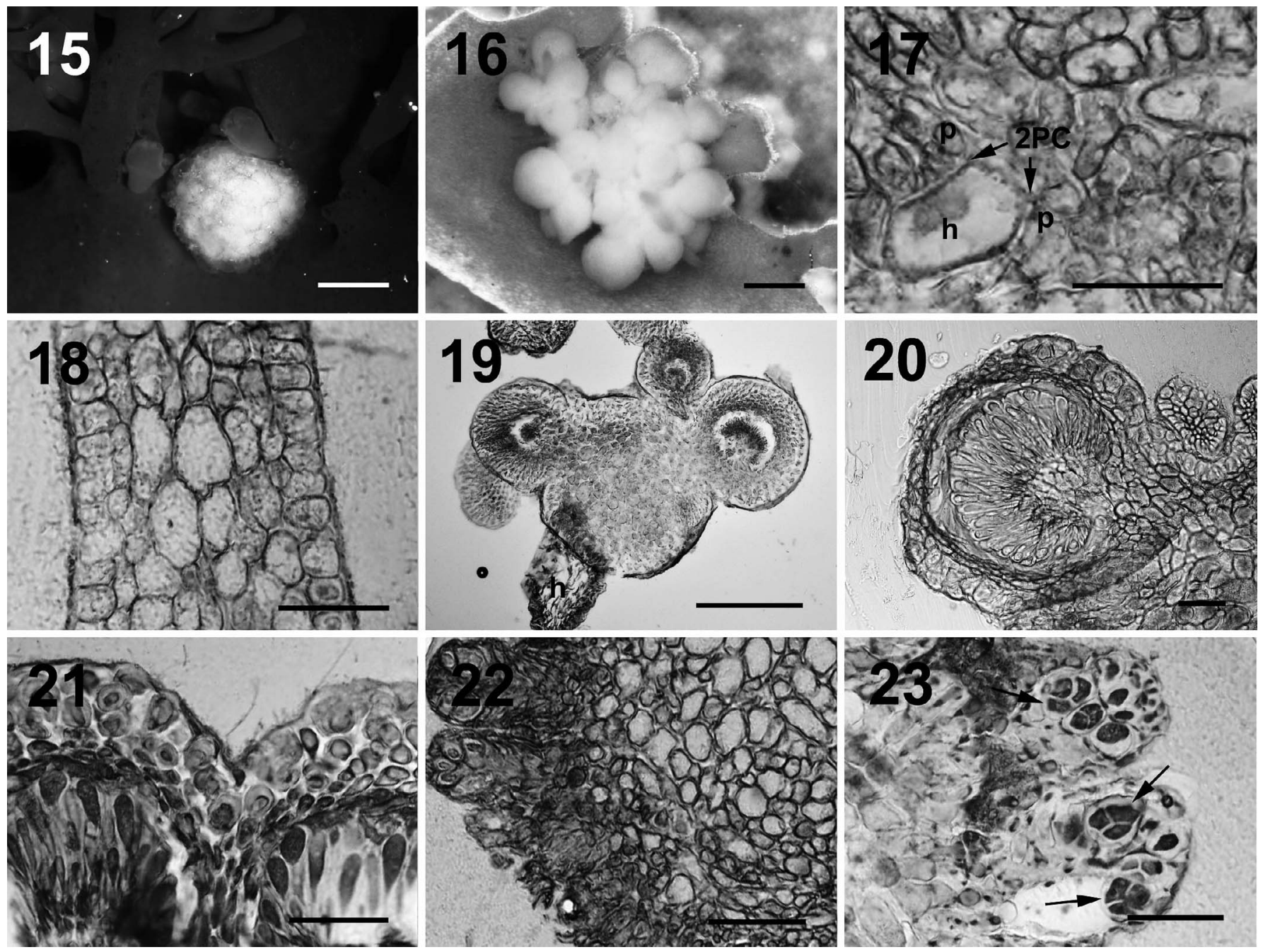

Figs 15-23. Vegetative and reproductive structures of Cladhymenia oblongifoliaphila and its host Cladhymenia oblongifolia.

Fig. 15. Tetrasporophytic parasite thallus growing between the lateral proliferations of its host. Scale bar $=1 \mathrm{~mm}$.

Fig. 16. Parasitic female gametophyte, with enlarged cystocarps, on host. Scale bar $=550 \mu \mathrm{m}$.

Fig. 17. Contact area between parasite and host cells. Parasite cell (p) forms secondary pit connection (2PC; arrow) with host cell (h). Scale bar $=100 \mu \mathrm{m}$.

Fig. 18. Internal anatomy of uninfected host, Cladhymenia oblongifolia, not disrupted by parasite penetration and used as guide for distinguishing between parasite and host cells in the contact area. Scale bar $=100 \mu \mathrm{m}$.

Fig. 19. Cross section of female Cladhymenia oblongifoliaphila with multiple cystocarps. Scale bar $=500 \mu \mathrm{m}$.

Fig. 20. Close-up of cystocarp, showing thick ostiole-less pericarp and carposporophyte. Scale bar $=100 \mu \mathrm{m}$.

Fig. 21. Close-up of pericarp and elongated carpospores. Scale bar $=100 \mu \mathrm{m}$.

Fig. 22. Tetrasporophytic thallus, showing internal anatomy and cluster of tetrasporangia. Scale bar $=200 \mu \mathrm{m}$.

Fig. 23. Tetrasporic clusters with tetrahedrally divided tetraspores (arrows). Scale bar $=100 \mu \mathrm{m}$.

DISTRIBUTION: Te Papa herbarium collections contained 91 specimens of Cladhymenia oblongifolia, and on eight of these, parasites were observed (Table S7). The parasite was found from the north $\left(36^{\circ} 57^{\prime} \mathrm{S}\right)$ to the south of the North Island $\left(41^{\circ} 21^{\prime} \mathrm{S}\right)$ and on the Chatham Islands (latitude $=44^{\circ} 16^{\prime} \mathrm{S}$ ). The parasite is not common and has a patchy distribution.

\section{Habitat and vegetative morphology}

One host plant had over 20 parasites growing on the blade edges and marginal proliferations (Fig. 15). The parasite was found in spring (September, November), summer (January, February) and autumn months (March, April) in New Zealand (Tables S1 and S7).
The parasite thallus was not pigmented, approximately 2 $\mathrm{mm}$ in diameter (Fig. 16). The base of the parasite penetrated deeply into the host thallus. Host and parasite cells were intermixed in the contact area. Secondary pit connections were found between small parasite cells and larger host cells in the contact area (Fig. 17). The vegetative structure of the host Cladhymenia oblongifolia consists of five inner layers of large cells, an outer layer of smaller epidermal cells and a cuticle (Fig. 18).

\section{Reproductive morphology}

Female gametophytes and tetrasporophytes were observed. Thalli bear either one rough roundish cushion (tetraspor- 
ophyte; Fig. 15) or many smooth spheres of different size (female gametophyte; Fig. 16). All observed parasites were reproductive but males were not found. Female gametophytes were found on tetrasporophytic host plants.

Mature female gametophytes had c. 30 cystocarps, these were approximately $520-570 \mu \mathrm{m}$ in diameter (Fig. 19). Pericarp had five to seven cell layers, approximately $100 \mu \mathrm{m}$ thick, without an ostiole (Fig. 20). Carposporangia were clavate to lachrymiform, 55-100× 14-24 $\mu \mathrm{m}$ (Fig. 21).

Internally the tetrasporophytes consisted of many round to oval large cells of different sizes (Fig. 22). The tetrasporophytes formed small clusters on their surface, which contained tetrasporangia. Branches were $300 \mu \mathrm{m}$ long by $150 \mu \mathrm{m}$ wide. Tetrasporangia were approximately $45-55 \mu \mathrm{m}$ in diameter and tetrahedrally divided (Fig. 23).

\section{Comparison between host and parasite}

The parasite shared the location of tetrahedrally divided tetraspores and the location of cystocarps with its host Cladhymenia oblongifolia but differed in thallus size and pigmentation (Table S8).

\section{Parasite on Blastophyllis calliblepharoides and Blastophyllis hombroniana}

Individual trees of $c o x 1$, LSU rRNA and $r b c \mathrm{~L}$ (Supplementary Figs S3-S5) showed that the parasite's closest relative is Judithia delicatissima (R.E.Norris) D'Archino \& Showe M.Lin with high support for $\operatorname{cox} 1$ and $r b c \mathrm{~L}$ and good support for LSU rRNA. The congruent results in all three markers supported a concatenated data set for a more robust phylogeny.

The concatenated data set ( $c o x 1$, LSU rRNA and $r b c \mathrm{~L})$ contained 44 taxa and was 4827 bp long with representatives of the two host species and their parasites. This dataset showed strong support for the shared origin of the parasite and Judithia delicatissima. Both host species, Blastophyllis calliblepharoides and Blastophyllis hombroniana, grouped together with high support (Fig. 24) and were not closely related to their parasites but this relationship was not well supported.

The phylogenetic data for this parasite with markers of the three different genomes supported a shared ancestry of the parasite with Judithia delicatissima. Callocolax neglectus described on Callophyllis laciniata (Hudson) Kützing (Batters 1895) from Europe was once recorded on Blastophyllis hombroniana (as Callophyllis hombroniana) from New Zealand (Cotton 1907) but most New Zealand Callophyllis spp. were shown to be different genera within the Kallymeniaceae (D'Archino et al. 2016, 2017), and the shared ancestry with endemic Judithia suggested that this parasite is most likely a new parasite species.

\section{Judithia parasitica M.Preuss \& Zuccarello sp. nov. Figs 25-30}

DIAGNOSIS: Thalli pigmented (pale red), less than $1 \mathrm{~mm}$ across, with wide base and multiple simple branches. Female and male gametophytes unknown. Tetrasporangia $26 \times 13 \mu \mathrm{m}$, cruciately divided, scattered on the surface of branches. Parasitic on Blastophyllis calliblepharoides and Blastophyllis hombroniana.
GENBANK ACCESSION NUMBERS: cox1, MF319180; LSU, MF319130; $r b c \mathrm{~L}, \mathrm{MF} 319137$.

HOLOTYPE: WELT A033495, collected 18 April 2012, deposited in Museum of New Zealand Te Papa Tongarewa.

ISOTYPE: WELT A033495, collected 18 April 2012, deposited in Museum of New Zealand Te Papa Tongarewa.

TYPE LOCALITY: $41^{\circ} 20.5^{\prime} \mathrm{S}, 174^{\circ} 48.634^{\prime} \mathrm{E}$; drift; Moa Point, Wellington, New Zealand.

ETYMOLOGY: parasitica $($ Latin $=$ parasitic) refers to the parasitic lifestyle of this alga.

DISTRIBUTION: Te Papa collections contained 44 specimens of Blastophyllis calliblepharoides, and parasites were observed on one specimen from Snares Island $\left(48^{\circ} 01^{\prime} \mathrm{S}\right)$, a subantarctic island of New Zealand. On 17 of the 45 specimens of Blastophyllis hombroniana parasites were found. The specimens were from Bank Peninsula $\left(43^{\circ} 45^{\prime} \mathrm{S}\right)$ on the South Island $\left(46^{\circ} 36^{\prime} \mathrm{S}\right)$, on Stewart Island and on the Auckland Islands $\left(50^{\circ} 30^{\prime} \mathrm{S}\right)$, a subantarctic island of New Zealand (Table S9).

\section{Habitat and vegetative morphology}

Judithia parasitica grows on Blastophyllis calliblepharoides (previously Callophyllis calliblepharoides) and Blastophyllis hombroniana (previously Callophyllis hombroniana). The position of the parasite and its abundance on the two hosts appeared similar. The hosts had up to a few hundred parasites growing mainly on the edges of the main axes or branches (Fig. 25). The parasite on B. calliblepharoides was found in autumn (April), summer (December), and on B. hombroniana in summer (December, January, February), autumn (March), winter (July, August) and spring (October, November) in New Zealand (Table S1, S9).

Thalli of Judithia parasitica were light red, with an average size of less than $1 \mathrm{~mm}(350-670 \mu \mathrm{m}$ length to $700-890 \mu \mathrm{m}$ in width). The parasite had a single, widely spreading base covering the host surface that did not penetrate deeply into the host thallus (Fig. 26). Parasite cells formed secondary pit connections with the top layer of cells (epidermal or subepidermal) of the host (Fig. 27). Parasite cells within the parasite thallus were highly connected to each other by either primary or secondary pit connections (Fig. 28).

\section{Reproductive morphology}

Tetrasporophytes were observed. Thalli bore multiple simple branches of different lengths with roundish tips. All observed parasite were either tetrasporophytic or non-reproductive; female and male gametophytes were not found.

The base of the tetrasporophyte produced multiple branches with inner elongated large cells and outer roundish small cells. Branches had tetrasporangia scattered on the surface (Fig. 29). Tetrasporangia were cruciately divided, approximately $13 \times 26 \mu \mathrm{m}(n=6$; Fig. 30$)$.

\section{Comparison of the parasite and its closest relative Judithia delicatissima}

Judithia parasitica sp. nov. shared scattered cruciately divided tetrasporangia of similar size with Judithia delicatissima. The 


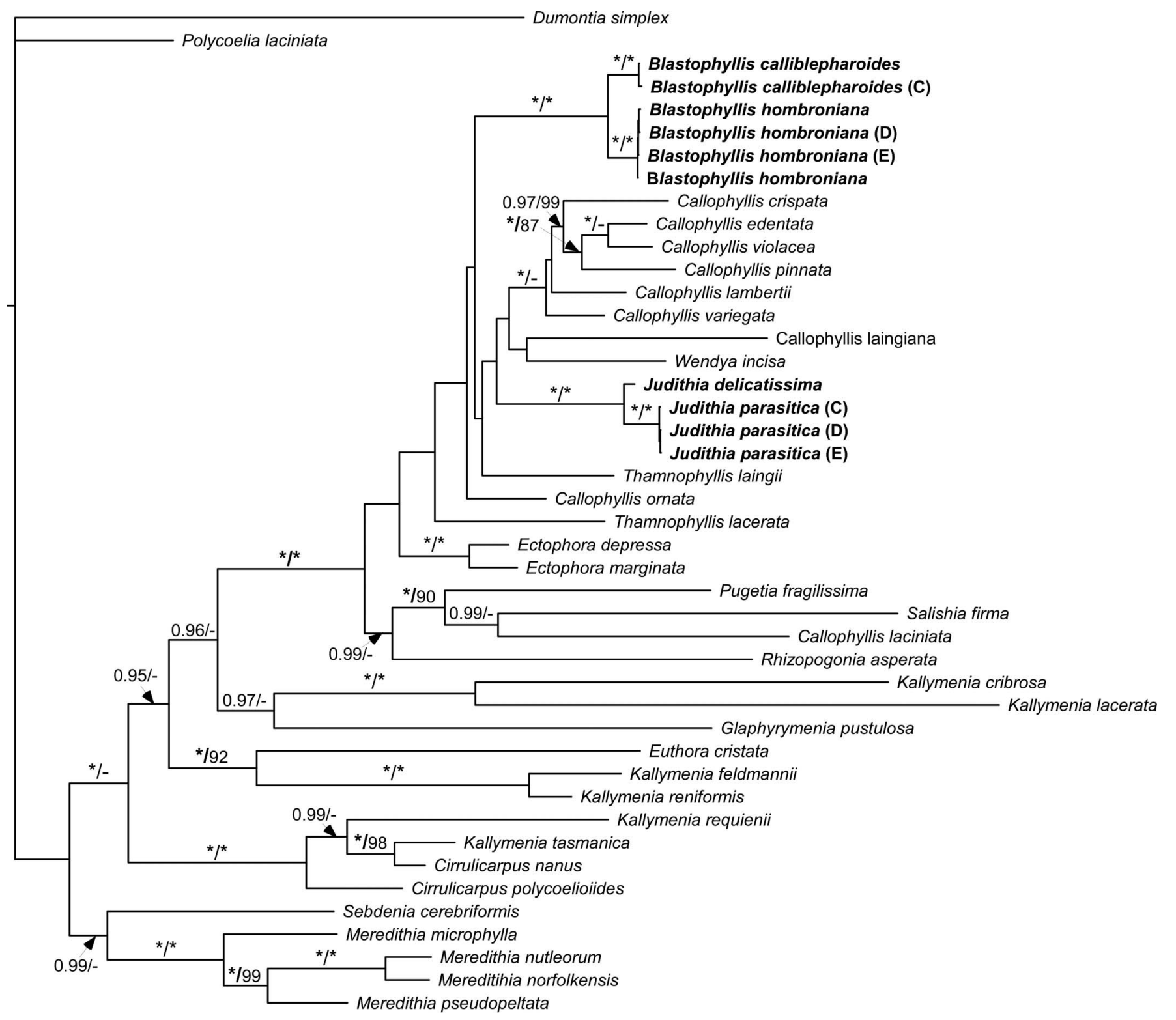

Fig. 24. Bayesian topology of concatenated $\operatorname{cox} 1, r b c \mathrm{~L}$ and LSU rRNA sequence data for the parasite Judithia parasitica and both hosts Blastophyllis calliblepharoides and Blastophyllis hombroniana plus other representative within the Kallymeniaceae. Parasite and host combinations are highlighted by capital letters in parentheses (C-E). New (Table S1) and Genbank samples (Table S3) were combined. Asterisks indicate posterior probability value of 1.00 and bootstrap value of $100 \%$. Values $<0.85$ posterior probability and $<85 \%$ ML bootstrap not shown. Outgroups Dumontia simplex Cotton and Polycoelia laciniata J.Agardh were removed to facilitate presentation.

parasite differed is overall thallus size and branching (Table S10).

\section{DISCUSSION}

This study describes three new red algal parasites from New Zealand that can be distinguished by their host specificity, growth form and reproductive structures. Our phylogeny indicates that the parasites share a common origin, in two cases, with their host genera (Phycodrys, Cladhymenia) or to a non-host genus (Judithia) that is in the same family (Kallymeniaceae) as the host genus (Blastophyllis).
A previous study hypothesized three different evolutionary scenarios of red algal parasite origin (Goff et al. 1996). First, some parasites (e.g. Bostrychiocolax australis Zuccarello \& J.A.West, Gardneriella tuberifera Kylin, Rhodophyllis parasitica) evolved from their hosts and solely infect this host species (Goff et al. 1996; Zuccarello et al. 2004; Preuss \& Zuccarello 2014). Second, parasites (e.g. Faucheocolax attenuata Setchell) evolved and grow on one host species but also parasitize a second, closely related host species (Goff et al. 1996). Third, some parasites (e.g. Plocamiocolax pulvinata Setchell) evolved on one species but now parasitize a secondary host and were lost from the original host species (Goff et al. 1996). Our data reflect the first and third scenario and reveal a possible fourth scenario. 

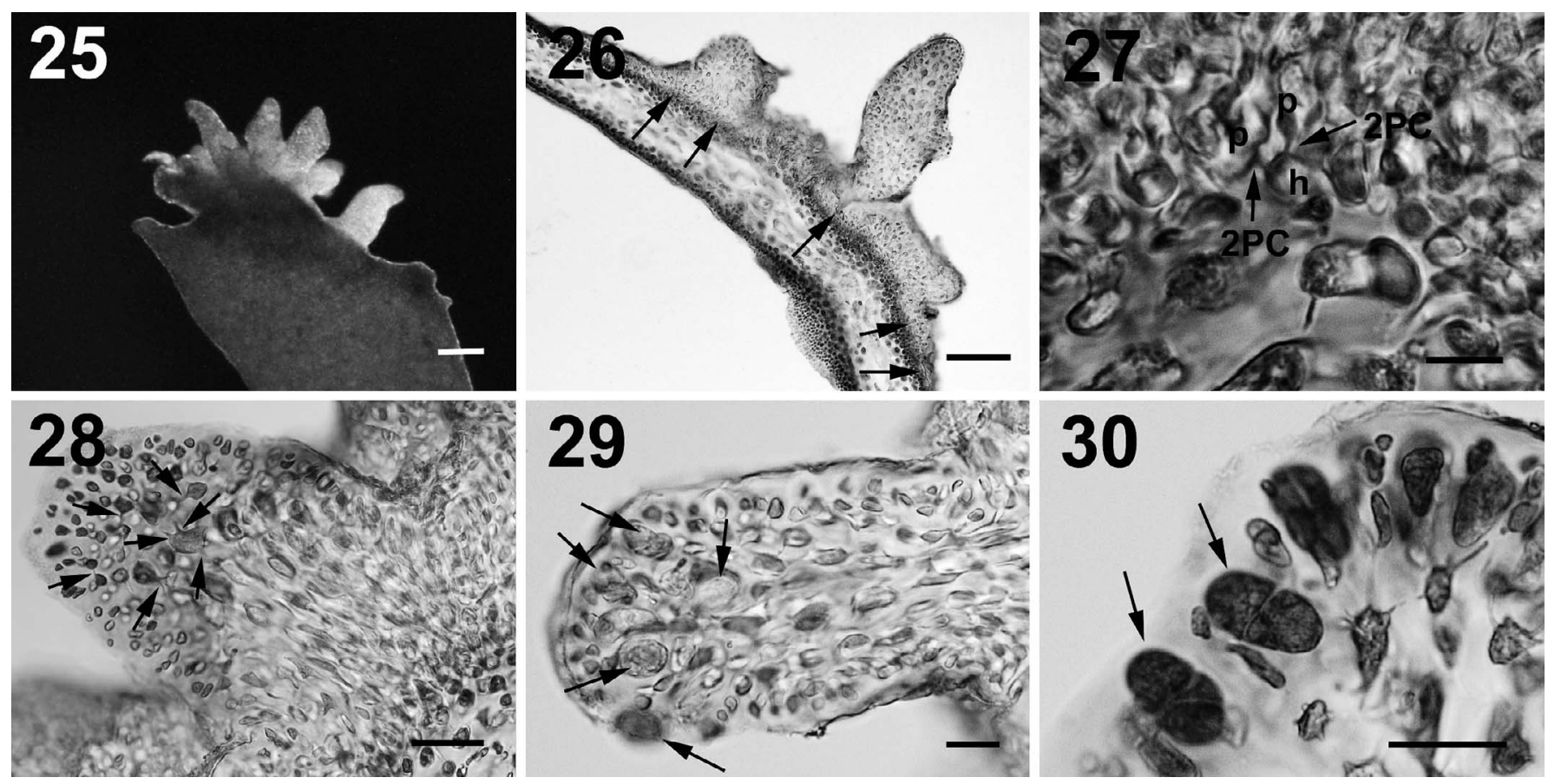

Figs 25-30. Vegetative and reproductive structures of Judithia parasitica growing on its host Blastophyllis hombroniana.

Fig. 25. Tetrasporophytic parasite on the edge of the host blade. Scale bar $=200 \mu \mathrm{m}$.

Fig. 26. Cross section of parasite thallus with wide base (arrows) growing over the host thallus. Scale bar $=10 \mu \mathrm{m}$.

Fig. 27. Parasite cells (p) with secondary pit connection (2PC; arrows) to pigmented host cells (h). Scale bar $=20 \mu \mathrm{m}$.

Fig. 28. Parasite cells are highly connected with each other by primary and secondary pit connections (arrows). Scale bar $=100 \mu \mathrm{m}$.

Fig. 29. Longitudinal section of tetrasporic branch with tetrasporangia (arrows) scattered over the surface. Scale bar $=20 \mu \mathrm{m}$.

Fig. 30. Close-up of cruciately divided tetrasporangia (arrows). Scale bar $=20 \mu \mathrm{m}$.

In the parasite Cladhymenia oblongifoliaphila mitochondrial and nuclear markers indicate that the parasite shares an origin with its host Cladhymenia oblongifolia; whereas, the plastid marker $(r b c \mathrm{~L})$ shows that its closest relative is the apparently non-host species Cladhymenia lyallii. There are several possibilities to explain the genetic patterns observed: (1) the parasite evolved from a common ancestor with $C$. oblongifolia and then switched host to $C$. lyallii, where it acquired plastids, as has been shown in Gracilaria babae $(\mathrm{Ng}$ et al. 2014), and subsequently switched back to $C$. oblongifolia and was lost from C. lyallii; (2) the species, sharing a common ancestry with $C$. oblongifolia, became a parasite on $C$. lyallii and acquired its plastid from this host, it then became a parasite of $C$. oblongifolia but was lost from C. lyallii; and (3) the species, sharing a common ancestry with $C$. oblongifolia, became a parasite on $C$. lyallii from which it acquired plastids and subsequently became a parasite of $C$. oblongifolia but has not been observed on $C$. lyallii.

Phycodrys novae-zelandiaephila is an example of a parasite that is genetically nearly indistinguishable from its host and found only on this host species. Genetic distances are higher within the host than between parasite and host. Other parasites have been recorded on Phycodrys species from other parts of the world (Asterocolax denticulatus, Asterocolax gardneri, Choreocolax rabenhorstii Reinsch). The common origin of $P$. novae-zelandiaephila with its host, and the close phylogenetic relationship of other Phycodrys parasites to their hosts (Goff et al. 1997), suggests that parasites have evolved multiple times in this genus. Why parasites have evolved so many times in some genera is not yet known.

Judithia parasitica growing on two Blastophyllis spp. is another possible example of host switching with extinction on the original host species (Goff et al. 1996). All molecular markers indicate that the closest relative of $J$. parasitica is Judithia delicatissima, and neither is closely related to the two hosts in Blastophyllis. Judithia parasitica either evolved on a shared common ancestor of Judithia as a parasite or as a free-living organism and became parasitic or switched hosts either to both species of Blastophyllis or to the common ancestor of these two species. Host switching to distantly related hosts is not common. One example is Harveyella mirabilis (Rhodomelaceae), which also parasitizes Gonimophyllum skottsbergii Setchell (Delesseriaceae) (Zuccarello et al. 2004).

Our study, and previous studies of different red algal parasites, showed that parasite and host are often sisterspecies (Goff et al. 1996, 1997; Zuccarello et al. 2004; Kurihara et al. 2010; Preuss \& Zuccarello 2014). Several parasitic relationships follow Emery's rule, originally developed for insects, that states that parasites are their hosts' closest relative (Emery 1909). These parasites evolved either by sympatric speciation from their host (Bourke \& Franks 1991) or were derived from two allopatrically non-parasitic species, one of which parasitize the other during secondary contact (Lowe et al. 2002). Emery's rule has been proposed for red algal parasites (Setchell 1918; Goff et al. 1997). 
Morphological characters of the three parasites are congruent with their phylogenetic relationships and confirm them as red algal parasites. All three parasites were small, with reduced or no pigmentation and formed secondary pit connections to their host's cells (Goff 1982; Wynne \& Scott 1989; Preuss et al. 2017). These criteria are the basis for many determinations of species as parasitic; nutrient status and detriment to the host have been seldom investigated (Martin \& Pocock 1953; Goff 1976, 1982; Kremer 1983; Apt 1984).

Our data support the placement of our parasite species in the genus of its closest relative and maintain a taxonomy based on monophyly. Modern classification should reflect phylogenetic relationships (de Queiroz \& Gauthier 1992), and we support the idea that the origin of these parasites should be reflected in their taxonomy. This may require that the circumscription of a genus that has been demonstrated to contain a parasitic species be modified to include it ('and the parasites derived from it'), as previously suggested (Preuss \& Zuccarello 2014).

A common taxonomic problem of red algal parasites is that names are applied to parasites found on hosts from distant areas or within the same host genus. Callocolax neglectus growing on Callophyllis laciniata was described from Europe (Batters 1895) but recorded on Callophyllis hombroniana (Cotton 1907) in New Zealand. No molecular data are available for Callocolax from the North Atlantic. Another example is Dawsoniocolax bostrychiae (A.B.Joly \& Yamaguishi-Tomita) A.B.Joly \& Yamaguishi-Tomita growing on Bostrychia radicans (Montagne) Montagne in Brazil (Joly \& Yamaguishi-Tomita 1969), which was later recorded on Bostrychia radicans in Australia (West \& Calumpong 1988) but phylogenetic and developmental studies showed that the Australian parasite is distinct (Bostrychiocolax australis, Zuccarello \& West 1994). These two examples make it obvious that careful morphological and anatomical observations, in addition to molecular data, of host and parasite are necessary to distinguish species.

In summary, we describe these three parasites as new species: Cladhymenia oblongifoliaphila sp. nov. (Ceramiales), Phycodrys novae-zelandiaephila sp. nov. (Ceramiales) and Judithia parasitica sp. nov. (Gigartinales) based on morphological and molecular evidence. The number of red algal parasites known from New Zealand has increased but further studies into this intriguing group are needed to understand their diversity, classification and evolutionary relationships with their hosts.

\section{ACKNOWLEDGEMENTS}

This research was supported by a student grant from the Wellington Botanical Society and the Hansjörg Eichler Fund from the Australasian Systematic Botany Society. We thank Wendy Nelson for samples and support, Roberta D'Archino for samples and training for hand sectioning, Caoimhghin Ó Maolagáin (NIWA, Wellington, NZ) for technical support and the TePapa museum for access to their herbarium. We thank two anonymous reviewers for helpful comments on the manuscript.

\section{SUPPLEMENTARY DATA}

Supplementary data associated with this article can be found online at http://dx.doi.org/10.2216/17-36.1.s1.

\section{REFERENCES}

Apt K.E. 1984. Effects of the symbiotic red alga Hypneocolax stellaris on its host Hypnea musciformis (Hypneaceae, Gigartinales). Journal of Phycology 20: 148-150.

Batters E.A.L. 1895. On some new British marine algae. Annals of Botany 9: 307-321.

BLouin N.A. \& LANE C.E. 2012. Red algal parasites: models for a life history evolution that leaves photosynthesis behind again and again. Bioessays 34: 226-235.

Blouin N.A. \& LANE C.E. 2015. Red algae provide fertile ground for exploring parasite evolution. Perspectives in Phycology 3: 1119.

Bourke A.F.G. \& Franks N.R. 1991. Alternative adaptations, sympatric speciation and the evolution of parasitic, inquiline ants. Biological Journal of the Linnean Society 43: 157-178.

Clement M., Posada D. \& Crandall K.A. 2000. TCS: a computer program to estimate gene genealogies. Molecular Ecology 9: $1657-1659$.

Cotton A.D. 1907. Marine algae from the Chatham Islands. Bulletin of Miscellaneous Information (Royal Botanic Gardens, Kew) 1907: 37-43.

D’Archino R., Lin S.-M., Gabrielson P.W. \& Zuccarello G.C. 2016. Why one species in New Zealand, Pugetia delicatissima (Kallymeniaceae, Rhodophyta), should become two new genera, Judithia gen. nov. and Wendya gen. nov. European Journal of Phycology 51: 83-98.

D'Archino R., Nelson W.A. \& Sutherland J.E. 2017. Neither Callophyllis nor Gelidium: Blastophyllis gen. nov. and Zuccarelloa gen. nov. (Kallymeniaceae, Rhodophyta) for three New Zealand species. Phycologia 56: 549-560.

de Queiroz K. \& Gauthier J. 1992. Phylogenetic Taxonomy. Annual Review of Ecology and Systematics 23: 449-480.

EMERY C. 1909. Über den Ursprung der dulotischen, parasitischen und myremekophilen Ameisen. Biologischen Centralblatt: 352362.

Felsenstein J. 1985. Confidence limits on phylogenies - an approach using the bootstrap. Evolution 39: 783-791.

GofF L.J. 1976. The biology of Harveyella mirabilis (Cryptonemiales; Rhodophyceae). V. Host responses to parasite infection. Journal of Phycology 12: 313-328.

Goff L.J. 1982. The biology of parasitic red algae. In: Progress in phycological research (Ed. by F.E. Round \& D.J. Chapman), pp. 289-369. Elsevier Biomedical Press, Amsterdam.

Goff L.J. \& Coleman A.W. 1995. Fate of parasite and host organelle DNA during cellular-transformation of red algae by their parasites. Plant Cell 7: 1899-1911.

Goff L.J., Moon D.A., Nyvall P., Stache B., Mangin K. \& Zuccarello G.C. 1996. The evolution of parasitism in the red algae: molecular comparisons of adelphoparasites and their hosts. Journal of Phycology 32: 297-312.

Goff L.J., Ashen J. \& Moon D.A. 1997. The evolution of parasites from their hosts: a case study in the parasitic red algae. Evolution 51: 1068-1078.

Joly A.B. \& Yamaguishi-Tomita N. 1969. Note on Dawsoniella Joly \& Yamaguishi-Tomita. Rickia 4: 209-210.

Kearse M., Moir R., Wilson A., Stones-Havas S., Cheung M., Sturrock S., Buxton S., Cooper A., Markowitz S., Duran C., Thierer T., Ashton B., Mentjies P. \& Drummond A. 2012. Geneious Basic: an integrated and extendable desktop software platform for the organization and analysis of sequence data. Bioinformatics 2: 1647-1649.

Kiм M.-S. \& Сно G.-Y. 2010. A new red algal parasite, Symphyocolax koreana gen. et. sp. nov. (Rhodomelaceae, Ceramiales), from Korea. Algae 25: 105-113. 
Kraft G.T. \& Aввотt I.A. 2002. The anatomy of Neotenophycus ichthyosteus gen. et sp. nov. (Rhodomelaceae, Ceramiales), a bizarre red algal parasite from the central Pacific. European Journal of Phycology 37: 269-278.

Kremer B.P. 1983. Carbon economy and nutrition of the alloparasitic red alga Harveyella mirabilis. Marine Biology 76: 231-239.

Kurihara A., Abe T., Tani M. \& Sherwood A.R. 2010. Molecular phylogeny and evolution of red algal parasites: a case study of Benzaitenia, Janczewskia, and Ululania (Ceramiales). Journal of Phycology 46: 580-590.

Lowe R.M., WARD S.A. \& CRozier R.H. 2002. The evolution of parasites from their hosts: intra- and interspecific parasitism and Emery's rule. Proceedings of the Royal Society B: Biological Sciences 269: 1301-1305.

Martin M.T. \& Pocock M.A. 1953. South African parasitic Florideae and their hosts. 2. Some South African parasitic Florideae. Journal of the Linnean Society of London, Botany 55: 48-64.

NG P.K., Lim P.E. \& Phang S.M. 2014. Radiation of the red algal parasite Congracilaria babae onto a secondary host species, Hydropuntia sp. (Gracilariaceae, Rhodophyta). PLoS One 9: e97450.

Olympus CellSens Software. https://www.olympus-lifescience. com/en/software/cellsens/.

Preuss M. \& Zuccarello G.C. 2014. What's in a name? Monophyly of genera in the red algae: Rhodophyllis parasitica sp.nov. (Gigartinales, Rhodophyta); a new red algal parasite from New Zealand. Algae 29: 279-288.

Preuss M., Nelson W.A. \& Zuccarello G.C. 2017. Red algal parasites: a synopsis of described species, their hosts, distinguishing characters and areas for continued research. Botanica Marina 60: $13-15$.

Ronquist F. \& Huelsenbeck J.P. 2003. MrBayes 3: Bayesian phylogenetic inference under mixed models. Bioinformatics 19: $1572-1574$

Salomaki E.D., Nickles K.R. \& Lane C.E. 2015. The ghost plastid of Choreocolax polysiphoniae. Journal of Phycology 51: 217-221.
Setchell W.A. 1918. Parasitism among the red algae. Proceedings of the American Philosophical Society 57: 155-172.

Stamatakis A. 2006. RAxML-VI-HPC: maximum likelihood-based phylogenetic analyses with thousands of taxa and mixed models. Bioinformatics 22: 2688-2690.

Townsend R.A. \& Huisman J.M. 2004. Epulo multipedes gen. et sp. nov. (Corallinaceae, Rhodophyta), a coralline parasite from Australia. Phycologia 43: 288-295.

Vergés A., Izquierdo C. \& Verlaque M. 2005. Rhodymeniocolax mediterraneus sp. nov. (Rhodymeniales, Rhodophyta), parasitic on Rhodymenia ardissonei from the western Mediterranean Sea. Phycologia 44: 510-516.

WeSt J.A. \& CAlumpong H. P. 1988. Dawsoniocolax bostrychiae (Choreocolacaceae, Gigartinales), an alloparasitic red alga new to Australia. Phycologia 27: 463-468.

Wynne M.J. \& Scott F. 1989. Pitycolax, a new genus of adelphoparasitic red algae from Ile Amsterdam, southern Indian Ocean. Cryptogamie, Algologie 10: 23-32.

ZucCAREllo G.C. \& LoKhORST G.M. 2005. Molecular phylogeny of the genus Tribonema (Xanthophyceae) using rbcL gene sequence data: monophyly of morphologically simple algal species. Phycologia 44: 384-392.

ZucCARello G.C. \& West J.A. 1994. Comparative development of the red algal parasites Bostrychiocolax australis gen. et sp. nov. and Dawsoniocolax bostrychiae (Choreocolacaceae, Rhodophyta). Journal of Phycology 30: 137-146.

Zuccarello G.C., West J., Kamiya M. \& King R. 1999. A rapid method to score plastid haplotypes in red seaweeds and its use in determining parental inheritance of plastids in the red alga Bostrychia (Ceramiales). Hydrobiologia 401: 207-214.

Zuccarello G.C., Moon D. \& Goff L.J. 2004. A phylogenetic study of parasitic genera placed in the family Choreocolacaceae (Rhodophyta). Journal of Phycology 40: 937-945.

Received 29 March 2017; accepted 14 July 2017 


\section{Corrigendum}

Correction to paper by Preuss, M. \& Zuccarello, G.C. 2018. Three new red algal parasites from New Zealand: Cladhymenia oblongifoliaphila sp. nov. (Rhodomelaceae), Phycodrys novae-zelandiaephila sp. nov. (Delesseriaceae) and Judithia parasitica sp. nov. (Kallymeniaceae). Phycologia 57: 9-19.

Two of the described species names are not in accordance with the International Code of Nomenclature for algae, fungi, and plants (Art 60.G.1, Orthography)

(1) removing the case ending of the genitive singular (Latin -ae, -i, -us, -is; transcribed Greek-ou, -os, -es, -as, -ous and its equivalent -eos) and

(2) before a consonant, adding a connecting vowel ( $-i$ - for Latin elements, $-o$ - for Greek elements) and the correct names are proposed below.

Cladhymenia oblongifoliophila M.Preuss \& Zucccarello sp. nov.

The diagnosis is provided in Phycologia 57: 13 (2018) and Figures 13-23.

Phycodrys novae-zelandiophila M.Preuss \& Zuccarello sp. nov.

The diagnosis is in Phycologia 57: 11 (2018) and Figures 1-12.

We thank Michael Wynne for nomenclatural assistance. 
Queries for phya-57-04-13

This manuscript/text has been typeset from the submitted material. Please check this proof carefully to make sure there have been no font conversion errors or inadvertent formatting errors. Allen Press. 